\title{
LOS PARADIGMAS DEL DERECHO PENAL: "EL PROGRESO DE LA CIENCIA A TRAVÉS DE LAS REVOLUCIONES CIENTÍFICAS"
}

\author{
Mariana N. Solari Merlo*
}

Resumen: La construcción de la cientificidad del derecho penal ha estado fuertemente marcada por los avances producidos en el ámbito de las ciencias más experimentales. El paradigma científico vigente en cada momento ha determinado su propio desarrollo y su necesidad de adaptarse, con mayor o menor esfuerzo, a los parámetros imperantes en otras áreas de conocimiento.

El análisis de esta evolución condicionada se propone, de modo novedoso, importando el modelo de sucesión de revoluciones científicas propuesto por el filósofo Thomas Kuhn, donde la acumulación de anomalías va a dar lugar a una revolución científica en la disciplina que acabará con la sustitución del paradigma por otro más acorde con la nueva realidad.

En la situación actual, no obstante, cabe preguntarse si las profundas transformaciones sociales que están teniendo lugar pueden hallar respuesta en el paradigma vigente o, por el contrario, es necesaria la adopción de soluciones más acordes.

* Profesora sustituta interina de la Universidad de Cádiz a tiempo completo y en el Máster universitario oficial en Sistema penal y criminalidad. Correo-e: mariana.solari@uca.es.Fecha de recepción: 28 de febrero de 2020. Fecha de aceptación: 12 de enero de 2021. Para citar el artículo: MARIANA N. SOLARI Merlo, "Los paradigmas del derecho penal: 'el progreso de la ciencia a través de las revoluciones científicas", Revista Derecho Penal y Criminología, vol. 41, n. ' 110, enero-junio de 2020, Bogotá, Universidad Externado de Colombia,pp.91-118. DOI: https://doi.org/10.18601/01210483.v41n110.05. 
Palabras clave: ciencia del derecho penal; revoluciones científicas; evolución del derecho penal.

\title{
THE PARADIGMS OF CRIMINAL LAW "THE PROGRESS OF SCIENCE THROUGH THE SCIENTIFIC REVOLUTIONS”
}

\begin{abstract}
The construction of the scientific nature of criminal law has been strongly marked by the advances made in the field of experimental sciences. The current scientific paradigm has determined its own development and its need to adapt, with more or less effort, to the parameters prevailing in other areas of knowledge.
\end{abstract}

The analysis of this conditioned evolution is proposed, in a novel way, by importing the model of succession of scientific revolutions proposed by the philosopher Thomas Kuhn, where the accumulation of anomalies will lead to a scientific revolution in the discipline that will end with the substitution of the paradigm for another more in line with the new reality.

In the current situation, however, it is worth asking whether the deep social transformations that are taking place can find an answer in the current paradigm or, on the contrary, it is necessary to adopt more appropriate solutions.

Keywords: science of criminal law; scientific revolutions; construction of criminal law.

\section{INTRODUCCIÓN}

En la primavera de 1636 Galileo se encontraba en su villa de Florencia inmerso en sus investigaciones científicas, aquellas que pocos años antes le habían supuesto la condena domiciliaria que ahora cumplía. Fue entonces cuando un acontecimiento fuera de lo habitual interrumpiría su rutina: el anuncio de que el duque de Devonshire y su preceptor, Thomas Hobbes, deseaban conocerlo ${ }^{1}$.

Comenzaría entonces una serie de encuentros propiciados por el filósofo que no vendrían sino a ahondar en la fascinación que éste mostraba por la razón, por la exactitud y por la búsqueda de respuestas científicas que no supusieran dogmas de fe ${ }^{2}$.

1 Esteve Pardo, El desconcierto del Leviatán. Política y derecho ante las incertidumbres de la ciencia, Madrid, Marcial Pons, 2009, pp. 9 y ss.

2 Es sabido que por aquel entonces Hobbes se hallaba inmerso en sus investigaciones sobre mecánica, lógica, psicología y óptica; su familiaridad con las teorías de grandes científicos como Copérnico, Kepler o Gassendi; sus estudios sobre Euclides; y sus buenas relaciones con Francis Bacon. Esta 
Fruto de estos intereses surgiría su obra culmen, Leviatán, donde presenta una sociedad que funciona en clave mecanicista regida por las ineludibles leyes de la naturaleza ${ }^{3}$. Al igual que el hombre puede ser entendido como un autómata cuya vida no es sino un movimiento de miembros -el corazón, su resorte; los nervios, diversas fibras; y las articulaciones, ruedas que dan movimiento al cuerpo entero-, "crea ese gran Leviatán que llamamos república o Estado [...] que no es sino un hombre artificial, aunque de mayor estatura y robustez que el natural para cuya protección y defensa fue instituido; y en el cual la soberanía es un alma artificial que da vida y movimiento al cuerpo entero; los magistrados y otros funcionarios de la judicatura y del poder ejecutivo, nexos artificiales; la recompensa y el castigo (mediante los cuales cada nexo y cada miembro vinculado a la sede de la soberanía es inducido a ejecutar su deber) son los nervios que hacen lo mismo en el cuerpo natural; la riqueza y la abundancia de todos los sus negocios; los consejeros, que informan sobre cuantas cosas precisa conocer, son la memoria; la equidad y las leyes, una razón y una voluntad artificiales; la concordia, es la salud; la sedición, la enfermedad; la guerra civil, la muerte" 4 .

El intento de aunar disciplinas y mundos en principio distantes no se limita al empirismo y al positivismo ${ }^{5}$. El deslumbramiento del derecho por las ciencias exactas está presente a lo largo de toda su historia. Los juristas, con mayor o menor énfasis, no han cesado en sus continuas aproximaciones, quizás en el entendimiento de que el conocimiento de la realidad debe ser lo más certero posible, por lo que el recurso a los aportes de las ciencias de la naturaleza se presenta como lo más fiable ${ }^{6}$.

proximidad a las ciencias experimentales constituiría la base de sus posteriores trabajos. En el mismo sentido, Hernández, El retrato de un dios mortal. Estudio sobre la filosofía política de Thomas Hobbes, Barcelona, Anthropos, 2002, p. 46.

3 González, "Mecanicismo en el Leviatán de Thomas Hobbes", en Ho Legon - Revista de Filosofía, año 13, n. ${ }^{\circ} 13,2009$, pp. 21-31.

4 Hobbes, Leviatán. La materia, forma y poder, de una República Eclesiástica y Civil, Bogotá, Skla, 1982, p. 11.

5 Un enfoque enriquecedor sobre el encuentro entre ciencias en Bilbeny y Guàrdia (eds.), Humanidades e investigación científica. Una propuesta necesaria, Barcelona, Universidad de Barcelona, 2015.

6 Sobre la necesidad de tener en cuenta otro tipo de conocimientos, Serrano-Piedecasas, "El conocimiento científico del Derecho penal", en Arroyo Zapatero y Berdugo Gómez de la Torre (coords.), Homenaje al Dr. Marino Barbero Santos. In memoriam, vol. I, 2001, pp. 659-698; y Gracia Martín que señala que son las doctrinas más punitivistas las que practica una especie de "solipsismo jurídicopenal" de modo que "operan conforme a una máxima según la cual 'las fronteras de mi derecho penal son las fronteras de mi mundo', y puesto que 'mi mundo es todo el mundo, el que yo no conozco, no existe’”, en Gracia Martín, "La serie ‘infracción-culpabilidad-sanción’ desencadenada por individuos libres como síntesis jurídica indisoluble derivada de la idea y del concepto a priori del derecho", RECPC, 18-18, 2016, p. 12. 


\section{ARISTAS DE LA RELACIÓN ENTRE EL DERECHO PENAL Y LAS CIRCUNSTANCIAS EXPERIMENTALES}

Son sabidas las importantes diferencias que en cuanto a objeto, finalidad y modos de proceder -racionalidad- existen entre la ciencia jurídica, especialmente el derecho penal, y las experimentales; y, aun así, están llamadas a entenderse. Cabe agrupar las múltiples aristas que conforman esta interrelación en tres grandes ámbitos: metodológico, estructural y material.

En un plano metodológico, como a continuación se expondrá, el positivismo jurídico tuvo su representación más importante de la mano de Binding y el estudio de las normas, pero los influjos naturalistas se expandieron por el propio contenido de las teorías. Así, los primeros estudios experimentales sobre el crimen en manos de juristas, médicos, psicólogos y profesionales afines condujeron al desprendimiento de la criminología como disciplina autónoma del derecho penal. Las hipótesis obtenidas, por muy erróneas que hoy puedan resultar a la luz de los avances del conocimiento, no pueden ser sino calificadas de científicas -según los parámetros de la época- y, por ende, un intento de aportar rigurosidad a la investigación.

Por otra parte, la relación con las ciencias de la naturaleza se extiende también hacia un plano estructural, llegando a influir en la propia columna vertebral del derecho penal en torno a la cual se configura su intervención. Así por ejemplo, basta pensar en el concepto mecanicista de acción ${ }^{7}$, la evolución del nexo causal $^{8}$, la configuración de la culpabilidad con base en los avances de la psicología o, más recientemente, de la ingeniería $\operatorname{artificial}^{9} \mathrm{y}$ de la física de partículas y las neurociencias ${ }^{10}$. Es decir, los contactos no sólo se limitan a las denominadas ciencias de la conducta ${ }^{11}$, que podría entenderse resultan auxiliares del derecho penal en determinadas ocasiones, sino que se extienden hacia áreas mucho más alejadas de esta materia ${ }^{12}$.

7 Roxin, Derecho penal. Parte General, tomo I: Fundamentos. La estructura de la Teoría del delito, trad. Luzón Peña, Díaz y García Conlledo y De Vicente Remesal, Madrid, Civitas, 1997, p. 235.

8 Ibíd., p. 342.

9 De la Cuesta Aguado, "La ambigüedad no es programable racionalización normativa y control interno en inteligencia artificial”, Revista de Derecho y proceso penal, n. ${ }^{\circ} 44,2016$, pp. 165-194.

10 Demetrio Crespo (dir.), Neurociencias y derecho penal: nuevas perspectivas en el ámbito de la culpabilidad y tratamiento jurídico-penal de la peligrosidad, Madrid, Edisofer, 2013; y monográfico de la revista InDret de abril de 2011.

11 Cfr. Zaffaroni, Tratado de Derecho penal. Parte general, t. I, Buenos Aires, Ediar, 1998, pp. 264 y ss.; y García-Pablos de Molina, Derecho penal. Introducción, Madrid, Servicio de publicaciones de la Facultad de Derecho de la Universidad Complutense de Madrid, 2000, pp. 511 y ss. En un sentido distinto, Bettinol, El problema penal, Buenos Aires, Hammurabi, 1995, pp. 84 y ss.

12 Sobre las implicaciones actuales del desarrollo científico y tecnológico, cfr. Herrera Moreno, M., "Nuevo naturalismo punitivo: aspectos de controversia en torno a los discursos penales de base evolucionaria", RECPC, 20-09, 2018; Ruiz Rodríguez, L. R., "La reforma penal de los delitos contra 
Finalmente, se debe considerar otra situación de relevancia que surge en torno a las múltiples vertientes de la relación intercientífica y es la producida por la proximidad en un plano material. Es decir, cuando son las propias ciencias naturales las que requieren la intervención jurídica en cuestiones estrictamente científicas que el derecho está llamado a regular.

En la sociedad actual, dominada por la ciencia y la tecnología, no es difícil imaginar diversas situaciones donde el Estado ha debido pronunciarse a efectos de ordenar determinado sector o prevenir posibles riesgos surgidos por el propio peligro de las actividades científicas. Así, por ejemplo, en materia de energía nuclear, genética, biotecnología, microorganismos, etc.

Las incompatibilidades entre ambos mundos - a saber, el derecho y el tecno-científicosuponen conflictos para el derecho penal y para las propias disciplinas objeto de regulación; en este último caso, por desconocer el derecho el fondo del funcionamiento de la materia. La situación del derecho penal, en cambio, resulta más grave ya que no son pocas las ocasiones en que se ve en la tesitura de alejarse de los principales postulados que la han conformado como ciencia a lo largo de toda su historia, haciéndola ineficiente en tanto es incapaz de ofrecer seguridad jurídica y ve continuamente vulnerados sus propios principios que constituyen el límite del Leviatán.

\section{EL PROGRESO CIENTÍFICO MEDIANTE REVELACIONES}

No es posible entender el progreso en el campo jurídico del mismo modo que se hace en el ámbito de las ciencias naturales. Los caminos avanzan no de un modo lineal sino tortuoso ${ }^{13}$, muchas veces sin un claro predominio de una teoría sobre otra. Como señala Mantovani, "sobre múltiples perfiles la historia del derecho penal no es sino un particular aspecto de la historia de la humanidad en su devenir de cursos y decursos, de evoluciones y de involuciones"14.

Es decir, como planteara Thomas Kuhn en La estructura de las revoluciones científicas $^{15}$, la ciencia no se desarrolla de un modo acumulativo mediante la mera adición

la salud pública como respuesta a las innovaciones científicas y tecnológicas”, RECPC, 18- 19, 2016; Solari Merlo, M. N., "Tecnociencia y Derecho. Análisis de la regulación penal del control de riesgos", Revista de Derecho de la UNED, n. ${ }^{\circ} 23,2018$, pp. 99-141; y, de la misma autora, "El legislador penal ante la innovación tecnológica. Los daños informáticos en el dilema entre la reflexión filosófica y la práctica jurídico científica”. En Moderno discurso penal y nuevas tecnologías memorias [del] III Congreso Internacional de Jóvenes Investigadores en Ciencias Penales, 17, 18 y 19 de junio de 2013, Salamanca, Universidad de Salamanca, 2014, pp. 201-217.

13 Morillas Cueva, L., "Reflexiones sobre el Derecho penal del futuro", RECPC, 04-06, 2002, p. 3.

14 Mantovani, F., Diritto Penale, P. G., 4. a ed., Padova, p. XXXVII, citado por Morillas Cueva, L. "Reflexiones sobre el Derecho penal del futuro", cit.

15 Kuhn, T. S., La estructura de las revoluciones científicas, México, FCE, 1975. 
de inventos y descubrimientos individuales, sino que son las comunidades científicas las que, en un actuar colectivo, establecen las creencias, los métodos, valores y conceptos que se consideran paradigmas de una época determinada.

Según el autor, los primeros momentos de desarrollo de la mayoría de las ciencias constituyen etapas precientíficas donde no puede hablarse de ciencia en sentido estricto. La primera amalgama de conocimientos va a venir conformada por la observación directa, la experimentación y las primeras reglas de manejo de instrumentos. A partir de ahí, se irán desechando los datos irrelevantes de aquellos realmente significativos, lo que vendrá a conformar las teorías vigentes en cada etapa histórica y constituir el paradigma en el que se inserten los distintos trabajos sobre la materia ${ }^{16}$.

En contra de los postulados de Popper, Kuhn entiende que en esta etapa los científicos no se dedican a poner a prueba las teorías; no hay intentos de refutación ni de crítica $^{17}$ sino que se produce un perfeccionamiento, una especialización, donde el objetivo prioritario es la organización y la articulación de los resultados obtenidos en forma de teoría. Lo relevante en esta etapa de formación del paradigma es "la determinación del hecho significativo, el acoplamiento de los hechos con la teoría y la articulación de la teoría"18.

En esta situación de ciencia normal, habrá un momento determinado en el que empiecen a surgir anomalías, esto es, supuestos relevantes que no puedan ser explicados a la luz del paradigma vigente. Estas anomalías son el primer síntoma de que el paradigma vigente no funciona del todo bien lo que conducirá, a la postre, a su abandono y sustitución por otro más adecuado ${ }^{19}$.

Ahora bien: una única anomalía no podrá nunca cuestionar la vigencia de un paradigma; puede haber irregularidades sin que por ello se ponga en tela de juicio el paradigma vigente ${ }^{20}$.

16 Echeverría, J. La revolución tecnocientífica, Madrid, FCE, 2003, p. 118.

17 La ciencia normal, señala Kuhn, "significa investigación basada firmemente en una o más realizaciones científicas pasadas, realizaciones que alguna comunidad científica particular reconoce, durante cierto tiempo, como fundamento para su práctica posterior". En La estructura de las revoluciones científicas, cit., p. 33

18 Ibíd., p. 66.

19 Como lo expone Lamo de Espinosa, "el cambio científico comienza con la percepción de una anomalía, es decir, con el reconocimiento de que un problema no puede resolverse por medio de los procedimientos establecidos por la ciencia normal, es decir, con la creencia de que la naturaleza ha violado las expectativas inducidas por el paradigma”. En Lamo de Espinosa, E. et al., La sociología del conocimiento y de la ciencia, Madrid, Alianza Editorial, p. 495.

20 Kuhn ejemplifica esta situación con tres supuestos: en primer lugar, con la vigencia del paradigma de Ptolomeo antes de la irrupción de las teorías de Copérnico; en segundo lugar, describe la crisis que precedió a la teoría de Lavoisier sobre la combustión del oxígeno; y, por último, a la crisis en la que estaba inserta la física a finales del siglo XIX y el surgimiento de la teoría de la relatividad. 
No obstante, cuando estas anomalías comienzan a ser recurrentes y a afectar al conjunto de la profesión es cuando se origina una situación de crisis. Los científicos trabajarán entonces en la resolución de problemas, haciendo surgir nuevas teorías que ofrecerán respuestas alternativas a la cuestión. Sólo cuando se disponga de una teoría alternativa, los científicos estarán dispuestos a abandonar el paradigma vigente.

Las revoluciones científicas se producen con la sustitución del paradigma vigente, lo que conlleva, a su vez, un cambio radical de conceptos, procedimientos e instrumentos. Es a través de la sustitución de paradigmas como la ciencia avanza. "La transición de un paradigma en crisis a otro nuevo del que pueda surgir una nueva tradición de ciencia normal, está lejos de ser un proceso de acumulación, al que se llegue por medio de una articulación o una ampliación del antiguo paradigma. Es más bien una reconstrucción del campo, a partir de nuevos fundamentos, reconstrucción que cambia algunas de las generalizaciones teóricas más elementales del campo, así como también muchos de los métodos y aplicaciones del paradigma"21.

En materia jurídica, no obstante, no es posible afirmar que las revoluciones se produzcan de un modo tan drástico. Los grandes hitos que marcan el progreso de la disciplina no suponen un completo abandono del modelo hasta entonces sostenido, pero sí tienen la suficiente relevancia como para marcar un importante avance en la ciencia del derecho penal. Como es lógico, esta relevancia y aceptación vendrá determinada por el grado de aceptación que, a su vez, generen las teorías dentro de la comunidad; como señala Serrano Maíllo, por el consenso intersubjetivo y racional ${ }^{22}$.

Como a continuación se expondrá, las principales revoluciones que ha tenido la ciencia penal se producen en un plano metodológico y estructural, y están fuertemente

Señala que, "aun cuando pueden comenzar a perder su fe y, a continuación, a tomar en consideración otras alternativas, no renuncian al paradigma que los ha conducido a la crisis. O sea, [no tratan] las anomalías como ejemplos en contrario, aunque, en el vocabulario de la filosofía de la ciencia, eso es precisamente lo que son". Véase Kuhn, T. S., La estructura de las revoluciones científicas, cit., pp. 115-127.

21 Kuhn, T. S., La estructura de las revoluciones científicas, cit., p. 139.

22 Cabe recordar, como apunta el autor, que "el criterio de consenso racional parte de la idea de que el investigador -o la comunidad-es libre, responsable, imparcial y honesto -dentro de unos límites-". En Serrano Maíllo, A., Ensayo sobre el Derecho penal como Ciencia. Acerca de su construcción, Madrid, Dykinson, 1999, pp. 58 y ss. En el mismo sentido, Calsamiglia, A., Introducción a la ciencia jurídica, 3. ' ed., Barcelona, Ariel, 1990, pp. 94 y ss.; Cuerda Riezu, A., El legislador y el Derecho penal (una orientación a los orígenes), Madrid, Centro de Estudio Ramón Areces, 1991, pp. 102 y ss.; Mir Puig, S., "Posibilidad y límites de una ciencia social del Derecho penal", en Mir Puig, S. Derecho penal y ciencias sociales, Barcelona, Universidad Autónoma de Barcelona, 1982, pp. 273 y 581; Bacigalupo Zapater, E., Delito y punibilidad, Madrid, Civitas, 1983, p. 34; Zugaldía Espinar,

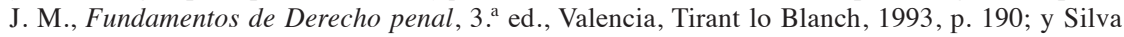
Sánchez, J. M., Aproximación al Derecho penal contemporáneo, Barcelona, José M. ${ }^{a}$ Bosch, 1992, p. 164. 
marcadas por los progresos que tienen lugar en las ciencias experimentales ${ }^{23}$. En la actualidad, no obstante, la expansión del plano material de esta relación está trayendo -nuevamente- importantes transformaciones para el derecho penal cuestionándose que pueda entenderse que se haya producido una revolución propiamente dicha.

\section{LAS REVOLUCIONES DEL DERECHO PENAL}

Se suele considerar que la aparición del derecho penal es tan antigua como lo es la convivencia civilizada en sociedad, momento en que el ser humano renuncia a ejercer todo tipo de venganza de propia mano y concede esa potestad al conjunto de la comunidad. El camino hacia la civilización ha sido el camino de la racionalización ${ }^{24}$, de la normativización. El castigo y la venganza privada se hacen públicos ya que sólo el soberano, en representación divina en un primer momento, está legitimado para restaurar el orden e impartir justicia. La pena se va tasando paulatinamente y el Estado asume así lo que tradicionalmente ha venido a denominarse ius puniendi, un derecho a castigar de titularidad exclusiva y excluyente de cualquier intromisión. Como lo expone Jiménez de Asúa, "la lucha entre la 'venganza de sangre' o la 'expulsión de la comunidad de la paz', reacciones de las tribus contra el delincuente, sin medida ni objeto, y el 'poder del Estado' para convertir en públicos los castigos, es un combate por la imparcialidad (y por ende, por el liberalismo) de nuestra rama jurídica. Con el talión, que da al instinto de venganza una medida y un fin, se abre el período de la pena tasada. Así se transforma en derecho penal público el poder penal ilimitado del Estado" 25 .

Ahora bien: siguiendo a Zaffaroni, es más apropiado interpretar que lo que asiste al Estado no es un derecho sino un deber de castigar ${ }^{26}$. Como señala el autor, "el estado no tiene 'derecho' a incriminar ni a penar, sino que tiene el deber de hacerlo,

23 Con un enfoque distinto, véase la obra de Pérez Alonso, E. J., "Las revoluciones científicas del Derecho penal: evolución y estado actual de la dogmática jurídico-penal”, ADPCP, t. L, 1997, pp. 185-209.

24 García-Pablos de Molina, A., Derecho penal. Introducción, cit., p. 104.

25 Jiménez de Asúa, L., Principios de Derecho penal. La ley y el delito, 3. a ed., Buenos Aires, AbeledoPerrot, Editorial Sudamericana, 1997, p. 31.

26 Con distintas argumentaciones, varios autores han señalado la falta de corrección de dicha fórmula. Así, según Jiménez de Asúa, es necesario revisar el empleo de estas viejas concepciones, “ya Manzini nos dijo que no había tal Derecho subjetivo del Estado, sino que la facultad de penar era un atributo de soberanía. En Francia, Duguit y sus discípulos han combatido contra los supuestos derechos subjetivos, y Kelsen ha hecho del deber jurídico base de su doctrina. En puridad, no hay derechos subjetivos, sino, más bien, pretensiones del sujeto activo. Así, por ejemplo, el Estado tiene la pretensión punitiva, que se extingue por numerosas causas que ahora no interesan, y también el individuo es capaz de poseerla aun en nuestra propia esfera jurídica: hay delitos que sólo se persiguen a instancias de parte". En Principios de Derecho penal. La ley y el delito, cit., p. 21. En el mismo sentido, como recoge Luzón Peña, se habla de "potestad punitiva estatal": Vasalli, La potestà punitiva, 1942, p. 99; Manzini, Tratado de Derecho penal, I, 1933, pp. 69 y 176; y Jescheck, Tratado de Derecho penal, 1978, p. 8, en Luzón Peña, D. M., “Alcance y función del Derecho penal”, ADPCP, tomo XLII, I, 1989, pp. 5-54. 
porque es un deber que surge de su función misma, es decir, de la propia razón de su existencia"27. Si el Estado gozase de tal derecho, "todos los delitos afectarían ese único 'bien jurídico', que no sería otro que el propio ius puniendi, cuyo titular es el Estado. No se penaría al homicida porque mató a otro y con ello le quitó la vida a un hombre, sino porque al matar a otro habría lesionado el supuesto derecho del Estado a regular la vida social" 28 .

Así, los orígenes del pensamiento penal se sitúan junto a los orígenes de la misma civilización en la antigua Mesopotamia; concretamente, en la Babilonia de Hammurabi entre los años 1792 y 1750 a. e. c. ${ }^{29}$. Desde entonces, cada cultura histórica se ha dotado de su propia legislación penal inspirada, como no puede ser de otro modo, en los principios y valores imperantes en cada momento, y ligada también al estado del conocimiento científico vigente entonces.

Poco se conserva de aquel incipiente derecho penal. La propia evolución de la sociedad supuso su obsolescencia. El derecho penal vigente es heredero de la época ilustrada, lleva en sus cimientos las elaboraciones teóricas de corte liberal con las que los ilustrados acabaron con el Antiguo Régimen y los privilegios y abusos asociados a tal modelo ${ }^{30}$. Es entonces cuando el ser humano se coloca sin complejos en el centro de su interpretación y se aleja, en mayor o menor medida, de justificaciones teológicas. El pensamiento ilustrado, contractualista y revolucionario, al margen de

27 Zaffaroni, E. R. Tratado de Derecho penal. Parte general, tomo I, cit., p. 33.

28 Ibídem,pp. 34-35.

29 Hammurabi fue el sexto rey de la I Dinastía de Babilonia que logró la unificación territorial de toda la región de Mesopotamia, caracterizada hasta entonces por las luchas constantes y la alternancia en el poder de las distintas ciudades. Su principal obra en el terreno jurídico fue la elaboración de un Código -el primero conocido- escrito en lengua semítica. No obstante, su grandeza no radica en la originalidad sino en las posibilidades de conocimiento que nos otorga, es decir, no se trata de una obra innovadora sino que Hammurabi va a recopilar y unificar las legislaciones ya existentes. El texto se encarga de regular no sólo cuestiones penales sino diversos aspectos de la vida en sociedad, principalmente relacionados con la propiedad, pública y privada. En el ámbito penal, el estilo utilizado es el de presentar las disposiciones en fórmulas condicionales: si ocurre tal cosa, se aplicará esta pena. Así, por ejemplo:

- "Si un hombre ha acusado a otro hombre y ha formulado un cargo de asesinato contra él, pero no lo ha probado, el acusador será ejecutado."

- "Si un hijo ha golpeado a su padre, le cortarán la mano."

Vázquez Hoys, A. M., Historia del mundo antiguo, vol. I. Próximo Oriente y Egipto, Madrid, Sanz y Torres, 2007, pp. 100 y ss.

30 Como señala Zugaldía, con anterioridad a la Revolución francesa, la legislación penal era eminentemente desigualitaria e imprecisa, residiendo el ejercicio de la justicia en manos de unos jueces que a su vez eran acusación y parte, e imponían penas atroces, crueles y desproporcionadas. Como ejemplo de dicha situación, baste la descripción del tormento sufrido por Robert Damiens, quien intenta dar muerte a Luis XV. Sin duda, la jornada sería ruda, tal como afirmara el condenado tras escuchar la sentencia que lo sometía a tormento ordinario y extraordinario. Zugaldía Espinar, J. M., Fundamentos de Derecho penal, cit., p. 182. 
sus diferencias internas, comparte el interés por el reconocimiento de los derechos subjetivos del ser humano y su trabajo se centrará en la justificación.

\subsection{La primera revolución}

En el momento en que comienza la verdadera reflexión sobre el significado del derecho penal ${ }^{31}$, debe entenderse que comienza también la cimentación de lo que hoy puede denominarse ciencia del derecho penal. No se trata de descartar de modo absoluto el pensamiento anterior ${ }^{32}$, pero lo que va a diferenciar este momento de otros pretéritos es que ni los pensadores griegos, ni San Agustín o Santo Tomás, entre muchos otros, siguieron un método riguroso alejándose mayoritariamente de justificaciones de corte teológico.

Como lo expone Zaffaroni, “la admisión de los 'derechos del hombre' en el derecho penal moderno no es el resultado de ninguna construcción unitaria, sino el de una amalgama filosófica y argumental bastante contradictoria, pero fundada en una actitud básica común, caracterizada por la elevación de la problemática de los derechos subjetivos al primer plano de la consideración jurídica, por oposición a las corrientes anteriores siempre inclinadas a destacar los deberes correlativos"33.

Es aquí cuando debe entenderse se produce la primera revolución en el sentido kuhntiano que traería un completo cambio en la forma de entender la cuestión criminal, el delito, la pena y los fines mismos del castigo. Los pensadores ilustrados trataron de hacer frente a las cuestiones sociales entonces acuciantes. Las ideas de libertad, igualdad y fraternidad que luego triunfarían con la Revolución sirvieron de base para el desarrollo de los principios que debían inspirar todo el sistema. Principios que en el ámbito penal adquirirán la consideración de límites a la coerción estatal.

31 Como señala Ferrajoli, superado el primer paso de regular la venganza como un derecho-deber privado, el siguiente paso, de mayor relevancia aun, "se marcó cuando se produjo una disociación entre el juez y la parte ofendida, de modo que la justicia privada -los duelos, los linchamientos, las ejecuciones sumarias, los ajustes de cuentas- fue no sólo dejada sin tutela sino también prohibida. El derecho penal nace precisamente en ese momento, o sea cuando la relación bilateral parte ofendida/ofensor es substituida por una relación trilateral, que ve en la tercera posición o como imparcial a una autoridad judicial. Es por esto que cada vez que un juez aparece animado por sentimientos de venganza o parciales, o de defensa social, o bien el Estado deja un espacio a la justicia sumaria de los particulares, quiere decir que el derecho penal regresa a un estado salvaje anterior al nacimiento de la civilización”. Ferrajoli, L., "El derecho penal mínimo", en Bustos Ramírez, J. (dir.), Prevención y teoría de la pena, Editorial Jurídica Cono Sur, p. 38.

32 De modo exhaustivo, sobre el pensamiento penal antiguo y medieval, cfr. Zaffaroni, E. R., Tratado de Derecho penal. Parte general, tomo II, Buenos Aires, Ediar, 1987, pp. 9-67. Asimismo Cuello Contreras, J., El derecho penal español. Parte general. Nociones introductorias. Teoría del delito, 3. a ed., Madrid, Dykinson, 2002, pp. 289 y ss.

33 Zaffaroni, E. R., Tratado de Derecho penal. Parte general, tomo II, cit., p. 74. 
En este sentido, la obra de Cesare Beccaria ${ }^{34}$ es sin duda la más afamada. Su grandeza radica no tanto en su originalidad sino en su capacidad de sintetizar con semejante maestría el pensamiento penal que se fraguaba entonces entre los ilustrados. Con Beccaria, señala Nuvolone, "el problema penal -comprensivo del problema sustancial y del problema procesal- aflora a la conciencia crítica, trayendo de la dialéctica también su autonomía desde un punto de vista lógico, que también permitirá superar las promesas y esperanzas del siglo de las luces: certeza, legalidad del proceso y de las penas, publicidad del procedimiento, instrumentalidad utilitaria y no venganza o retribución, distinción del tema jurídico-penal del tema moral. Al mismo tiempo, y como natural consecuencia, nace la ciencia del derecho y del proceso penal: nace como ciencia de la legislación, como problemática extra-positiva"35.

Las leyes penales debían estar orientadas a evitar la comisión de delitos en tanto estos suponían un ataque ilegítimo a la comunidad y una vulneración del pacto social que permitía la pacífica convivencia. El ser humano se coloca en el centro de esta concepción pero asociado íntimamente con la idea de vida en sociedad, posibilitada por el contrato social. Quien libre y voluntariamente, puesto que este es el modo de actuar de los hombres, comete un delito, desprecia y atenta contra esa armónica convivencia. El libre albedrío inherente a todos los hombres es lo que fundamenta su castigo.

En ese sentido, los términos del contrato han de estar claros, de ahí que se haga especial hincapié en el principio de legalidad y la claridad en la redacción de las leyes. Claridad que también sirve para reducir el resquicio dejado a la interpretación, susceptible siempre de arbitrariedad por parte de los jueces ${ }^{36}$.

Es de destacar la diversidad que presentan los distintos autores. Beccaria, más cercano al contractualismo al igual que Filangieri o Lardizábal, entre muchos otros, hace de este concepto el fundamento y límite de la coerción estatal. Otros autores, en cambio, presentan tintes más revolucionarios -y funcionalistas, según teorías posteriores-, como ocurre con Jean-Paul Marat ${ }^{37}$. Entienden estos últimos que las leyes penales

34 Beccaria, C., Tratado de los delitos y de las penas, Granada, Comares, 2008. Sobre los cuestionamientos de la autoría de su obra, Zaffaroni, E. R., Tratado de Derecho penal. Parte general, tomo II, cit., pp. 87 y ss.

35 Nuvolone, P., Trent'anni di diritto e procedura penale (Processo e pena nell'opera di Cesare Beccaria), I, Padova, 1969, p. 438, citado por Zaffaroni, E. R., Tratado de Derecho penal. Parte general, tomo II, cit., p. 89.

36 Como afirma Beccaria, "si es un mal la interpretación de las leyes, es otro evidentemente la oscuridad, que arrastra consigo necesariamente la interpretación, y aun lo será mayor cuando las leyes estén escritas en una lengua extraña para el pueblo, que lo ponga en la dependencia de algunos pocos, no pudiendo juzgar por sí mismo cual será la suerte de su libertad o de sus miembros, en una lengua que forma de un libro público y solemne uno casi privado y doméstico". Beccaria, C., Tratado de los delitos y de las penas, cit.

37 Así, por ejemplo, se justifica la resistencia al cumplimiento de ciertas leyes que no hacen más que perpetuar situaciones de injusticia provechosas para los poderosos. Como lo expone Marat, "Haced 
están indefectiblemente unidas al sistema político vigente en cada momento, por lo que no es posible su trasformación radical sin el consiguiente cambio de sistema. La idea de utilidad, bien general y defensa de la sociedad está presente de un modo u otro en todos estos pensadores, pero su interpretación varía.

Las ideas ilustradas fueron la base sobre la que luego evolucionarían los autores considerados clásicos. Resulta difícil, no obstante, caracterizar este pensamiento puesto que la denominada "escuela clásica" no lo fue en el sentido propio de la palabra. Sus representantes no tuvieron conciencia de pertenecer a ninguna corriente de pensamiento sino que su agrupación se impuso desde fuera y con posterioridad a su obra. Así, es coincidente la doctrina ${ }^{38}$ en señalar que fue el positivista Enrico Ferri ${ }^{39}$ quien con esta denominación, y de un modo un tanto despectivo fruto del autoritarismo de quien, como señala Zaffaroni, "considera que es el único poseedor de la verdad científica y caracteriza como metafísicos, precientíficos o clásicos a quienes aún no alcanzaron los niveles de su verdad" 40 , quiso diferenciar el pensamiento de sus predecesores como Carrara, Carmignani, Rossi, entre otros, del positivismo entonces en boga.

Lo cierto es que las ideas ilustradas que contribuirían a la desaparición del delito a través de la prevención no consiguieron tan utópico resultado. Como señala Cuello

abstracción de toda violencia, y encontraréis que el único fundamento legítimo de la sociedad es la felicidad de los que la componen. Los hombres no se han reunido más que por su interés común, no han hecho las leyes más que para fijar sus respectivos derechos, y no han establecido un gobierno más que para asegurar el goce de estos derechos. Si renuncian a su propia venganza, es porque la declinan en el brazo público; si renuncian a la libertad natural, es por adquirir la libertad civil; si renuncian a la primitiva comunidad de bienes, es para poseer en propiedad alguna parte de ellos... En una tierra que toda es posesión de otro y en la cual no se pueden apropiar nada, quedan reducidos a morir de hambre. Entonces, no conociendo la sociedad más que por sus desventajas ¿están obligados a respetar las leyes? No, sin género de duda; si la sociedad los abandona, vuelven al estado natural, y cuando reclaman por la fuerza derechos de que no pudieron prescindir sino para proporcionarse mayores ventajas, toda autoridad que se oponga a ello es tiránica, y el juez que los condene a muerte, no es más que un vil asesino". Marat, J. P., Plan de legislación criminal, Buenos Aires, Hammurabi, 2000, pp. 67-68.

38 Entre otros, Jiménez de Asúa, L., Principios de Derecho penal. La ley y el delito, cit., pp. 42 y ss.; Mir Puig, S., Introducción a las bases del Derecho penal. Concepto y método, 2. a ed., Buenos Aires, Euro Editores, Montevideo, B de F, 2003, pp. 154 y ss.; Zaffaroni, E. R., Alagia, A. y Slokar, A., Derecho penal. Parte general, 2. ${ }^{a}$ ed., Buenos Aires, Ediar, 2002, pp. 316 y ss.; y Morillas Cueva, L., Metodología y ciencia penal, Granada, Universidad de Granada, 1990, pp. 66 y ss.

39 Señala Zaffaroni que "la mayor genialidad de Ferri -al menos por el éxito que tuvo hasta el presente, en que se la reitera como verdad incuestionada- fue la invención de una inexistente escuela clásica del derecho penal, supuestamente integrada por todos los autores no positivistas, fundada por Beccaria y capitaneada por Carrara. Esta escuela abarcaba toda Europa y estaría integrada por pensadores iluministas de todas las nacionalidades, revolucionarios franceses, idealistas alemanes, aristotélicos y tomistas, criticistas y kantianos, hegelianos, krausistas, etc. Semejante escuela, que más parecería un parlamento pluripartidista, por supuesto que jamás existió, sino que a Ferri le resultó cómodo ponerle un rótulo común a todos los penalistas que no compartían sus puntos de vista". En Zaffaroni, E. R., Alagia, A. y Slokar, A., Derecho penal. Parte general, cit., p. 316. 
Contreras, este fue el pretexto para que los sectores más conservadores de la sociedad retornaran a concepciones más represivas de la criminalidad y de la pena. "De ahí que se volviera a un derecho penal puramente retributivo, pues es más fácil suponer que todo individuo es responsable de sus actos, que esforzare en comprender y atajar las causas de la criminalidad" 41 .

El método seguido, lógico-abstracto, se alejaba en gran medida de la realidad en la que pretendía incidir. Más cercano a concepciones morales y al derecho natural, la pena era entendida como un mal, necesaria en tanto medio de tutela de la sociedad y basada en el libre albedrío y la culpabilidad moral de su autor ${ }^{42}$. Como afirmara Carrara, "el derecho penal tiene su génesis y su forma en una ley absoluta, porque constituye el único orden posible de la humanidad según las previsiones y la voluntad del Creador... las demostraciones no se derivan de la palabra humana, sino que deben ser deducciones lógicas de la razón eterna, por la cual reveló Dios a los hombres, por admirable inspiración, cuanto es menester para regular su conducta con respecto a los propios semejantes. Subordinadas así a una norma absoluta, las leyes penales son absolutas en sus principios cardinales, y sólo pueden convertirse en relativas en su forma de aplicación"43.

El libre albedrío fue una pieza clave de esta concepción que justifica no sólo la imposición de las penas sino también la igualdad de las leyes. Como apunta Mir Puig ${ }^{44}$, este idealismo llevaba hasta las últimas consecuencias la premisa liberal de que todos los hombres igualmente libres. Así, formalmente la ley garantizaba un trato igualitario, pero no era así en un plano material. Establecer diferencias según las necesidades de cada cual, esto es, tratar de modo distinto aquello que es diferente, entraba en oposición con el método abstracto de la escuela clásica, situación que no se corrigió hasta la admisión de las circunstancias modificativas de la responsabilidad.

\subsection{La segunda revolución}

La concepción del mundo y la forma de aproximarse a la realidad, es decir, objeto y método condicionan los resultados que se materializarán en la praxis. Hacia finales del siglo XIX, el proceso de industrialización se extendía por sectores cada vez más amplios de la Europa occidental, trayendo consigo el ideal de progreso basado en los avances puramente científicos. Es el auge del positivismo que, comenzando por

41 Cuello Contreras, J., El Derecho penal español. Parte general. Nociones introductorias. Teoría del delito, cit., p. 325

42 Jiménez de Asúa, L., Principios de Derecho penal. La ley y el delito, cit. p. 46 y Bacigalupo Zapater, E., Manual de Derecho penal. Parte general, Bogotá, Temis, 1996, pp. 42 y ss.

43 Carrara, F., Programa del curso de derecho criminal, I, trad. esp. de Jiménez de Asúa, L., 2. ${ }^{\text {ed }}$., Madrid, 1925, p. 13.

44 Mir Puig, S., Introducción a las bases del Derecho penal. Concepto y método, cit., p. 159. 
el Círculo de Viena y la Concepción Heredada, fue impregnando las distintas ramas científicas entre las que se encuentra el derecho. En materia penal se va a producir una bifurcación que supondría la distinción del positivismo jurídico de otro de corte sociológico-naturalista.

Es decir, en este nuevo modelo de sociedad que se estaba conformando, el idealismo ya no parecía la metodología más apropiada para aproximarse a la realidad. La siguiente revolución en el campo del derecho penal se produce en el momento en que el positivismo se convierte en el método elegido.

Binding es el máximo exponente de primer positivismo. Al igual que haría Kelsen, centrará su trabajo en el análisis exclusivo del derecho positivo, rechazando todo juicio de valor o referencia a la realidad metajurídica. Como señala Muñoz Conde, "Binding consideraba que la única misión del penalista consistía en la interpretación del derecho penal positivo y en eso veía, al mismo tiempo, su orgullo. La ley positiva, considerada como un todo objetivo, es el único objeto y punto de partida para un jurista" 45 .

Por contraposición, el positivismo naturalista iba a pretender una aproximación más radical a las ciencias de la naturaleza, acercándose a su método empírico de trabajo e importando sus conceptos. El éxito del evolucionismo y de las ciencias naturales de la época fueron determinantes para el impulso del positivismo naturalista, al igual que lo fueron las causas de carácter político. Otra de las consecuencias del surgimiento de la sociedad industrial fue el aumento de la criminalidad hacia finales de siglo, culpándose a la escuela clásica de la ineficacia de atajar el problema mediante métodos tan abstractos y alejados de la realidad ${ }^{46}$.

La nueva sociedad introduciría un nuevo actor en escena, el proletariado, que ya no podía contentarse con esa libertad meramente formal de épocas pretéritas. No se necesita un reconocimiento sino una remoción efectiva de las condiciones que dificultan su consecución. Es decir, un cambio de modelo de Estado abstencionista -liberal-a uno intervencionista orientado a la protección de esta nueva clase desfavorecida y oprimida por los empresarios.

Esta concepción tendrá su reflejo en el derecho penal. "Si el Estado liberal había propugnado un derecho penal de garantía, despreocupado de incidir en la realidad y más bien preocupado en no hacerlo, el nuevo Estado social estaba llamado a encarnar un derecho penal de prevención efectiva. Se saldría así al paso del importante

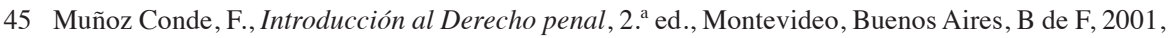
p. 175.

46 Mir Puig, S., Introducción a las bases del Derecho penal. Concepto y método, cit. 
aumento de la delincuencia que produjo la industrialización" 47 . Pero, como señala el autor, la filosofía de un derecho penal intervencionista se volvió en contra de su impulsor siendo el proletariado el principal sujeto criminalizado dada su falta de adaptación a la nueva sociedad industrial.

Es entonces cuando se afirma que tiene lugar el nacimiento de la criminología como disciplina autónoma del derecho penal. Autores como Lombroso, Ferri o Garófalo, entre otros, centraron su interés no tanto en el delito como en el delincuente tratando de identificar mediante el estudio empírico factores determinantes de la inclinación hacia el crimen. Esto supone la negación de la premisa fundamental mantenida por la escuela clásica que es el libre albedrío. El delito, al ser un fenómeno de la naturaleza, se rige por sus mismas reglas, entre ellas la causalidad. Luego habría determinadas causas que impulsarían a los hombres a delinquir, es decir, no es una decisión autónoma, una elección, sino un carácter que viene determinado biológicamente.

Son sabidas las consecuencias que se derivan de estas hipótesis cercanas al fascismo. En la distinción de los diferentes tipos de delincuentes se produce una clasificación en atención a su peligrosidad. La prevención está asociada a la temprana identificación a efectos de imponer el tratamiento adecuado, por lo que las medidas de seguridad pasan a un primer plano, desplazando a la pena como el castigo adecuado. Los delincuentes atávicos, no obstante, al no tener remedio, deben ser excluidos de la sociedad, inocuizados, puesto que constituían una amenaza constante.

En el plano jurídico el positivismo naturalista también tuvo su representación. El denominado "modelo clásico" del derecho penal fue fruto directo de la interpretación naturalista y causalista de la realidad. Como señala Sueiro, hasta la misma elaboración de la teoría del delito se volvió un estudio estratificado del delito, esto es, "la examinación del hecho delictivo en planos o niveles [...] consecuencia de la adopción directa de la escuela causalista del método científico empleado por la geología, la cual revela la antigüedad de los objetos conforme al estrato o plano de sedimentación de la tierra en el cual se encuentra" 48 .

Entre los cuatro niveles de análisis - acción, antijuridicidad, culpabilidad y punibilidad-, especial relevancia tiene la distinción entre el plano objetivo y el subjetivo, lo externo al ser humano, verificable y determinado por las leyes de la naturaleza, y lo interno, la culpabilidad, entendida como el nexo psicológico que relaciona conducta y resultado. Como lo definiría Von Liszt, una acción es "la realización de una mutación en el mundo exterior atribuible a una voluntad humana. A esta mutación la llamamos resultado. Su realización es atribuible a la voluntad humana cuando

47 Ibíd., p. 197.

48 Sueiro, C. C., Los paradigmas del Derecho penal. Sobre la armonía metodológica del derecho penal, Buenos Aires, Fabián J. Di Plácido, 2011,pp. 219-220. 
resulta de un movimiento corporal de un hombre, quejido o, lo que es lo mismo, arbitrario. De este modo, el concepto de acción se divide en dos partes: de un lado el movimiento corporal y del otro el resultado, ambos unidos por la relación de causa y efecto"49; idéntica definición a la apuntada por Beling, quien afirmara que "debe entenderse por 'acción' un comportamiento corporal (fase externa, 'objetiva' de la acción) producido por el dominio sobre el cuerpo (libertad de inervación muscular, 'voluntariedad'), (fase interna, 'subjetiva' de la acción); ello es, un 'comportamiento corporal voluntario', consistente ya en un 'hacer' (acción positiva), ello es, un movimiento corporal, p. ej. levantar la mano, movimientos para hablar, etc., ya en un 'no hacer' (omisión), ello es, distensión de los músculos" $" 50$.

No obstante, el método del positivismo pronto comenzó a presentar anomalías que conducirían a su cuestionamiento y ulterior abandono ${ }^{51}$. La objeción fundamental, señalada por Berdugo Gómez de la Torre y Terradillos Basoco ${ }^{52}$, es la relativa a la insuficiencia de su concepto de ciencia. Para aprehender la totalidad de la realidad no basta con los métodos de las ciencias naturales, es preciso complementarlos con la metodología exclusiva de las ciencias culturales ${ }^{53}$. Es el auge del neokantismo, que vendría a revalorizar el papel de las ciencias del espíritu, dotándolas de autonomía frente a las ciencias de la naturaleza, y afirmando su verdadero estatus científico.

El descrédito que, con carácter general, adquirió el positivismo pronto llegó al derecho penal. Como lo describe Fasso, "la misma palabra positivismo, que había sido la orgullosa bandera de una sociedad pagada de las grandes conquistas de su ciencia, pasó a significar esta limitación visual y cae en descrédito, hasta ser utilizada, aun sin razón, para liquidar doctrinas molestas: exactamente como los positivistas habían hecho con la palabra metafísica (o incluso con filosofía)" 54 .

En el ámbito penal, estas anomalías se manifestaban en las principales categorías de la teoría del delito. En relación con la acción, la concepción causalista era incapaz

49 Von Liszt, F., Lehrbuch, 1891, p. 128, citado por Zaffaroni, E. R., Alagia, A. y Slokar, A., Derecho penal. Parte general, cit., p. 402.

50 Von Beling, E., Esquema de Derecho penal. La doctrina del delito-tipo, Buenos Aires, Rodamillans, 2002 , p. 42.

51 Señala Mir Puig que en el área del Derecho penal este abandono se produce con anterioridad que en el Derecho privado, situándose en la década de 1920, mientras que en las restantes ramas del ordenamiento estuvo vigente hasta el período de entreguerras. En Mir Puig, S., Introducción a las bases del Derecho penal. Concepto y método, cit., p. 207.

52 Berdugo Gómez de la Torre, I. y Terradillos Basoco, J., "Lección 3. Historia de la Ciencia del Derecho penal", en Demetrio Crespo, E. y Rodríguez Yagüe, C. (coords.), Curso de Derecho penal. Parte

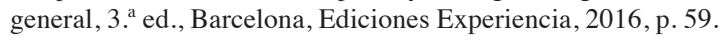

53 Muñoz Conde, F., Introducción al Derecho penal, cit., p. 177.

54 Fasso, G., Storia della filosofía del diritto, III, Bologna, 1970, p. 262, citado por Mir Puig, S., Introducción a las bases del Derecho penal. Concepto y método, cit., p. 211. 
de incorporar satisfactoriamente la omisión al tratarse este de un concepto normativo; lo mismo ocurría con la antijuridicidad, la concepción naturalista impedía la entrada de elementos subjetivos; y en relación con la culpabilidad, su entendimiento como nexo causal supone la identificación de esta con el dolo y la culpa, no quedando espacio para el análisis de la imputabilidad ni de las causas de exclusión de la culpabilidad; menos aún para la culpa inconsciente.

En la ciencia penal, el neokantismo se divide en dos direcciones principales: la de Marburgo, cuyo máximo exponente es Stammler ${ }^{55}$, y la sudoccidental alemana, de mayor relevancia para nuestra disciplina. En esta última, destaca especialmente la figura de Lask, de quien suele afirmarse que dotó a la disciplina de los fines y valores inherentes a lo jurídico, y Radburch, quien pese a no abandonar el positivismo, lo complementa subsanando algunas de sus limitaciones.

No obstante, como señala Welzel ${ }^{56}$, el neokantismo debe ser considerado más bien un complemento del positivismo jurídico y, en ese sentido, no puede entenderse que se trate de una auténtica revolución en el sentido que se viene analizando. Radbruch parte de la férrea distinción entre el plano del ser y del deber ser, y la imposibilidad, tomada de la idea kantiana de derivar el deber ser del ser, de obtener valores de la realidad. "El reino de los valores y el mundo de los hechos coexisten como dos órbitas paralelas, sin entrecruzarse. Esta relación entre el valor y la realidad, entre el ser y el deber ser, es lo que se llama el dualismo metodológico de troncar las leyes naturales en verdaderas normas" "57. A partir de aquí, como es sabido, el empleo del dualismo metodológico supondrá una modificación en el método. El objeto del derecho seguiría teniendo los mismos caracteres naturalistas, lo que cambiaría sería el método de conocimiento. El conocimiento de los objetos se produce a través de la dimensión valorativa de los sujetos. Como señala Silva Sánchez, "el neokantismo no hace de esa dimensión valorativa un 'objeto’ de estudio por sí mismo. Los valores son objeto de reflexión en la medida en que constituyen la 'lente de pensar' a través de la que el sujeto contempla una realidad en sí caótica, sin sentido" 58 .

55 Señala García-Pablos de Molina que Stammler "pretendió 'explicar la dogmática como ciencia e impedir que se el reproche que, científicamente, carece de valor'. Siguiendo la teoría del conocimiento de Kant, distingue Stammler la materia de la forma, y, sobre todo, las ciencias causales (las naturales) y las ciencias finales (la del Derecho, por ejemplo): en las primeras, los fenómenos se ordenan con arreglo a la relación causa-efecto; en las segundas, a la de medio-fin. Esta distinción permitiría fundamentar la independencia metódica de la Ciencia del Derecho, ajustada a las relaciones de medio-fin de las que ésta se ocupa”. En García-Pablos de Molina, A., Derecho penal. Introducción, cit., p. 482.

56 Welzel, H., Introducción a la Filosofía del Derecho: Derecho natural y Justicia material, 2. ed., Madrid, Aguilar, 1979, pp. 198-199.

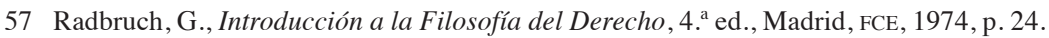

58 Silva Sánchez, J. M., Aproximación al Derecho penal contemporáneo, cit., p. 55. 
Pese a las contradicciones en que este planteamiento incurre al intentar introducir correcciones valorativas sobre una base causalista positivista, son de destacar los aportes para la ciencia del derecho penal que, junto a los continuadores de esta postura como son Mezger y Sauer, se han obtenidos. Así, se produce por primera vez la aceptación de elementos subjetivos en el plano de la acción -aunque continuaba vigente el concepto causal-en relación, por ejemplo, con la tentativa, los elementos subjetivos del injusto, la esencia valorativa de la antijuricidad o la función teleológica del bien jurídico. Al margen de estos importantes avances, la aportación fundamental ha sido la de proporcionar a los juristas su objeto de estudio, distinguiendo los diversos puntos de vista desde los que aproximarse a los problemas suscitados en torno al delito y a la pena. Como señala Muñoz Conde, "el neokantismo viene a delimitar los campos: el delito puede ser estudiado desde un punto de vista causalexplicativo y ser objeto de la criminología, pero también puede ser estudiado como un fenómeno jurídico objeto de valoraciones y ser, por tanto, objeto de la ciencia del derecho penal. Ambos tipos de consideraciones son, científicamente hablando, lícitas e incluso recomendables, y fueron precisamente autores influenciados por esta corriente filosófica los que comenzaron a estudiar los problemas penales desde distintas perspectivas, causales y valorativas, sin confundirlas ni mezclarlas" $" 59$.

\subsection{La tercera revolución}

Cuando el finalismo entra en escena, antes del comienzo de la Segunda Guerra Mundial, se va a erigir como la propuesta alternativa más completa para superar el neokantismo. En este sentido, supone la tercera revolución importante que ha sufrido la ciencia del derecho penal. Como señala Hassemer, "la teoría de la acción final desde un comienzo irrumpió con una arrogancia propia de la conciencia de su valor y armada con fuertes pertrechos" $" 60$.

La teoría de Welzel se propone como superadora del subjetivismo metodológico y el relativismo valorativo de los neokantianos proponiendo una concepción objetiva de corte realista aristotélica ${ }^{61}$, en el entendimiento de que el error fundamental de aquellos radicaba en una incorrecta interpretación de las categorías de la razón kantianas ${ }^{62}$.

Así, su metodología ontologicista sobre la que construye su teoría del delito se fundamenta en la configuración de las estructuras lógico-objetivas ${ }^{63}$, esto es, la existencia

59 Muñoz Conde, F., Introducción al Derecho penal, cit., p. 180.

60 Hassemer, W., "La ciencia jurídico penal en la República Federal Alemana", $A D P C P$, t. XLVI, 1993, p. 45.

61 Sueiro, C., Los paradigmas del Derecho penal. Sobre la armonía metodológica del derecho penal, cit., p. 229.

62 En profundidad, cfr. Silva Sánchez, J. M., Aproximación al Derecho penal contemporáneo, cit. p. 59.

63 Sobre las estructuras lógico-objetivas y la naturaleza de las cosas, véase García-Pablos de Molina, A., Derecho penal. Introducción, cit., pp. 170-176; Gimbernat Ordeig, E., Concepto y método de la 
de verdades eternas que trascienden al ser humano. En contra de lo mantenido por el neokantismo, el sujeto no configura el objeto sino que este existe y está conformado con independencia de su entendimiento. Será el objeto, en todo caso, el que determinará el método y no al contrario.

Estas estructuras lógico-objetivas, que ya tienen incorporada la dimensión de sentido ${ }^{64}$, condicionan a la dogmática y al legislador en las valoraciones que puedan realizar al aproximarse a la realidad, constituyendo un límite para este último ${ }^{65}$. A partir de su conocimiento podrá decidir cuál es la regulación más adecuada para las distintas cuestiones penales.

Entiende Welzel que las estructuras lógico objetivas fundamentales en derecho penal son, por un lado, el carácter final de las acciones y, por otro, el entendimiento de la culpabilidad como reprochabilidad ${ }^{66}$. En relación con la primera, como es sabido, entiende el autor que mientras que las ciencias naturales se interesan por las acciones en tanto fenómenos naturales guiados por las leyes de la causalidad, al derecho penal le interesa su componente espiritual, esto es, "conforme a sentido" 67 . En palabras del propio autor, "la acción humana es ejercicio de actividad final. La acción es, por tanto, un acontecer 'final' y no solamente 'causal'. La 'finalidad', o el carácter final de la acción, se basa en que el hombre, gracias a su saber causal, puede prever, dentro de ciertos límites, las consecuencias posibles de su conducta, asignarse, por tanto, fines diversos y dirigir su actividad, conforme a un plan, a la consecución de estos fines"68.

En cuanto a su concepción de la culpabilidad, se basa en la autodeterminación. "Culpabilidad es la reprochabilidad de la resolución de la voluntad. El autor habría podido adoptar en lugar de la resolución de voluntad antijurídica -tanto si va dirigida dolosamente a la realización del tipo, como si no responde a la medida mínima exigida de dirección final- una resolución de voluntad conforme con la norma. Toda culpabilidad es, pues, culpabilidad de la voluntad. Sólo aquello que depende de algún modo de la voluntad del hombre puede serle reprochado como culpable"69.

ciencia del Derecho penal, Madrid, Tecnos, 2009, pp. 99-102; y Cerezo Mir, J., "La naturaleza de las cosas y su relevancia jurídica", en su obra Problemas fundamentales del Derecho penal, Madrid, Tecnos, 1982, pp. 39 y ss.

64 Silva Sánchez, J. M., Aproximación al Derecho penal contemporáneo, cit., p. 58.

65 Mir Puig, S., Introducción a las bases del Derecho penal. Concepto y método, cit., pp. 233-234.

66 A estas estructuras habría que añadir, como señala Silva Sánchez, la relación entre autoría y participación y la necesidad de que el hecho principal sea siempre doloso. Silva Sánchez, J. M., Aproximación al Derecho penal contemporáneo, cit.

67 Mir Puig, S., Introducción a las bases del Derecho penal. Concepto y método, cit., p. 232.

68 Welzel, H., El nuevo sistema del Derecho penal. Una introducción a la doctrina de la acción finalista, trad. Cerezo Mir, J., Montevideo, Buenos Aires, B de F, p. 41.

69 Ibíd., p. 133. 
Estas consecuencias se derivan de la propia estructura lógico-objetiva del ser, están ancladas en la esencia del ser humano y, por tanto, no pueden ser ignoradas en la construcción de la teoría del delito.

Hassemer ha señalado la cercanía de este pensamiento con los postulados del nacionalsocialismo y el "derecho penal de la voluntad". No hay que olvidar que la teoría se retrotrae a comienzos de la década de 1930, por lo que, entiende, comparte ciertas bases con el ideario de la época ${ }^{70}$. Tras analizar esta cuestión, no obstante, señala Frommel que el autor, en su fase inicial, "no se era consciente de la función legitimadora del sistema que estaba cumpliendo. Un buen ejemplo de ello es el reproche que Welzel dirige a Radbruch de haber favorecido con su 'relativismo' la entrega del derecho al poder"71 así como el hecho de que las estructuras lógico-objetivas tienen una clara misión explícita por Welzel de limitar el poder del legislador, no justificarlo.

Son conocidas las objeciones que se plantean al concepto final de acción en relación con su imposibilidad de abarcar la omisión y la imprudencia en su definición, así como la confusión que se le atribuye de pretender derivar deberes de cualidades ontológicas, esto es, del mero $\operatorname{ser}^{72}$. Así, pese a que esta concepción ha sido mayoritariamente abandonada no puede entenderse que en el siguiente período se produzca una revolución en el sentido hasta ahora expuesto. Más bien, como señala Silva, se trata de sistemas de signo ecléctico que alcanzan diferentes niveles de coherencia ${ }^{73}$.

\subsection{Etapa posrevolucionaria}

Inspiradas en las elaboraciones teóricas sociológicas de Parsons, en Estados Unidos, y especialmente Luhmann, en Alemania, surgen los desarrollos funcionalistas de corte sistémico en la doctrina penal. Sus derivados pueden conducir a posturas peligrosas que, como señala Zaffaroni ${ }^{74}$, se sitúan en las antípodas del derecho penal de corte liberal y garantista. Así, en su versión moderada, la propuesta de Roxin ${ }^{75}$ pretende la

70 Hassemer, W., "La ciencia jurídico penal en la República Federal Alemana”, cit., pp. 44 y ss.

71 Frommel, M., "Los orígenes ideológicos de la teoría final de la acción de Welzel”, ADPCP, t. XLII, II, 1989, p. 630.

72 En profundidad,Zaffaroni, E. R., Alagia, A. y Slokar, A., Derecho penal. Parte general, cit., pp. 399 y ss.; Cerezo Mir, J., La polémica en torno al concepto finalista de autor en la ciencia del Derecho penal española, $A D P C P$, tomo XXVIII, 1975, pp. 41-56; del mismo autor, "La influencia de Welzel y del finalismo, en general, en la Ciencia del Derecho penal española y en la de los países iberoamericanos", ADPCP, tomo LXII, I, 2009, pp. 67-92; Gracia Martin, L., Fundamentos de dogmática penal. Una introducción a la concepción finalista de la responsabilidad penal, Barcelona, Atelier, 2006.

73 Silva Sánchez, J. M., Aproximación al Derecho penal contemporáneo, cit., p. 63.

74 Zaffaroni, E. R., Hacia un realismo jurídico penal marginal, Caracas, Monte Ávila, 1993, pp. 59 y ss.

75 Roxin, C., Política criminal y sistema del derecho penal, trad. Muñoz Conde, F., 2. ed., Buenos Aires, Hammurabi, 2002. Para una contraposición entre su postura y la de Jakobs, del mismo autor, "El nuevo desarrollo de la dogmática jurídico-penal en Alemania”, InDret, octubre, 2012. 
superación de la tradicional contraposición entre derecho penal y política criminal, asociando al injusto los fines del derecho penal, esto es, la protección secundaria de bienes jurídicos; mientras que el momento de la culpabilidad guardaría relación con los fines de la pena ${ }^{76}$.

En su versión más extrema, Jakobs hace de la protección de la vigencia de la norma la base de su sistema ${ }^{77}$, resultando como consecuencia la confusión entre injusto y culpabilidad. Esta ya no se determina con base en las capacidades del autor del delito, sino de acuerdo a las necesidades sociales.

Inserto también en el funcionalismo pero con una postura completamente distinta se encuentra la mantenida por Hassemer, defensor del mantenimiento del derecho penal clásico, de corte liberal y garantista, y muy crítico con la relajación de principios que en los últimos tiempos ha venido sufriendo la disciplina a causa de la denominada "sociedad del riesgo"78.

76 Como lo expone el propio autor, "se debe partir de la tesis de que un moderno sistema del Derecho penal ha de estar estructurado teleológicamente, o sea construido atendiendo a finalidades valorativas. Pues si la solución sistemáticamente correcta aparece como resultado de una valoración previa, estará garantizada de antemano la concordancia entre la consecuencia (congruencia) sistemática y la corrección material pretendida, cuya falta ha dado lugar a tantas dificultades [...]. Las finalidades rectoras que constituyen el sistema del Derecho penal sólo pueden ser de tipo político-criminal, ya que naturalmente los presupuestos de la punibilidad han de orientarse a los fines del Derecho penal". En Roxin C., Derecho penal. Parte General, t. I. Fundamentos. La estructura de la Teoría del delito, cit., p. 217.

77 En profundidad, Jakobs, G., Derecho penal. Parte general. Fundamentos y teoría de la imputación, trad. Cuello Contreras, J. y Serrano González de Murillo, J. L., Madrid, Marcial Pons, 1995; “Imputación jurídicopenal: desarrollo del sistema a partir de las condiciones de vigencia de la norma”, en Jakobs, G. y Struensee, E., Problemas capitales del derecho penal moderno. Libro homenaje a Hans Welzel, Buenos Aires, Hammurabi, 1998, pp. 33-55; y, “¿Qué protege el Derecho penal: bienes jurídicos o la vigencia de la norma?", en Montealegre Lynett, E. (coord.), El funcionalismo en Derecho penal. Libro homenaje al profesor Günther Jakobs, Bogotá, Universidad Externado de Colombia, 2003, pp. 39-56, donde afirma que "el derecho penal garantiza la vigencia de la norma, no la protección de bienes jurídicos. En este punto, los representantes de la tesis de la protección de bienes jurídicos objetarán que ello de ningún modo debe ser una contraposición; por el contrario, dirán, lo decisivo es limitar el derecho penal a la protección de la vigencia de aquellas normas que prohíben afectar a un bien, y deslegitimar las demás normas, especialmente, aquellas que se caracterizan por proteger determinadas convicciones morales". No obstante, entiende que esto no es posible "pues los bienes [...] presentan determinadas condiciones de supervivencia sin las cuales no pueden ser usados, y también habría que proteger esas condiciones de subsistencia”, p. 43.

78 Pese a que se suele caricaturizar a la Escuela de Frankfurt como contraria a toda modernización y defensora acérrima de un bien jurídico individual y monista, sí reconocen la existencia de bienes jurídicos universales. Baste leer la enérgica respuesta de Prittwitz, discípulo de Hassemer, a la caracterización que realizara Schünemann de la doctrina, "los ataques de Schünemann me parecen no sólo lingüísticamente excesivos, sino poco convincentes, dado que una doctrina monista y personal del bien jurídico reconoce absolutamente bienes jurídicos universales y nada, salvo la retórica petulancia y combatividad de Schünemann, obliga a esta doctrina, en el conflicto entre 'la más insensata veleidad del individuo egoísta' y 'las condiciones de vida de las futuras generaciones', a tomar partido por la primera". En Prittwitz, C., "Sociedad de riesgo y Derecho penal", en Arroyo Zapatero, L., 
En el mismo sentido reduccionista o minimalista se sitúan las posturas de Zaffaroni y Ferrajoli, respectivamente. En el primer caso, entiende el autor que la función reductora que debe cumplir la dogmática se fundamenta en la tendencia expansionista del poder estatal $^{79}$. "Cuando el derecho penal debe elaborar conceptos, no puede desconocer que aun cuando no lo haga teleológicamente, éstos cumplen una función política y, por ende, no le resta otra alternativa que orientarlos políticamente, so pena de construir conceptos perversos. Para no caer en la perversidad debe eludir la tendencia a inventar lo que en el mundo no existe, como así también a pretender que lo que existe lo limita más allá de la necesidad"80.

La propuesta de Ferrajoli ${ }^{81}$ trata también de minimizar el derecho penal, abogando por un mayor garantismo. Para esto, se trata de reconstruir las categorías dogmáticas desde los principios propios del Estado democrático ${ }^{82}$, limitando así el ejercicio del ius puniendi. Como lo expone el autor, "el fin del derecho penal no puede reducirse a la mera defensa social de los intereses constituidos contra la amenaza representada por los delitos. Dicho fin supone más bien la protección del débil contra el más fuerte, tanto del débil ofendido o amenazado por el delito, como del débil ofendido o amenazado por las venganzas; contra el más fuerte, que en el delito es el delincuente y en la venganza es la parte ofendida o los sujetos con ella solidarios [...]. En ambos aspectos la ley penal se justifica en cuanto ley del más débil, orientada hacia la tutela de sus derechos contra las violencias arbitrarias del más fuerte. De este modo, los derechos fundamentales constituyen precisamente los parámetros que definen los ámbitos y los límites como bienes, los cuales no se justifica ofender ni con los delitos ni con las puniciones" ${ }^{\prime 3}$.

Las propuestas se han multiplicado desde la década de 1960 hasta ahora, generando un panorama un tanto caleidoscópico debido, en parte, al crecimiento acompasado de la población dogmática. No obstante, como se ha comentado, no puede afirmarse que ningunas de ellas haya supuesto una revolución en el sentido expuesto. En la

Neumann, U. y Nieto Martín, A. (coords.), Crítica y justificación del Derecho penal en el cambio de siglo, Ediciones de la Universidad de Castilla - La Mancha (Estudios: 91), Cuenca, 2003, p. 270.

79 Esto se basa en la asunción de que la pena es incapaz de cumplir los fines que tradicionalmente le vienen asignados. Como señala el autor, "al asignar al derecho penal la función política de dique colocado por el estado de derecho para contener la presión del estado de policía, y con el valor negativo asignado al poder punitivo en general y a la pena en particular (a partir de una posición agnóstica acerca de sus funciones manifiestas), no puede eludirse la consecuencia de que la construcción conceptual del delito deba llevarse a cabo como un sistema orientado por la idea rectora de su intencionalidad reductora del poder punitivo". En Zaffaroni, E. R.,Alagia,A. y Slokar, A., Derecho penal. Parte general, cit., p. 348.

80 Ibíd., p. 347.

81 Ferrajoli, L., Derecho y razón. Teoría del garantismo penal, Madrid, Trotta, 1995.

82 Berdugo Gómez de la Torre, I. y Terradillos Basoco, J., "Lección 3. Historia de la Ciencia del Derecho penal", cit., p. 63.

83 Ferrajoli, L., "El derecho penal mínimo", cit., p. 39. 
actualidad, de hecho, parecería algo del todo imposible que alguna teoría remueva al sistema penal como lo han hecho las revoluciones comentadas.

Debe aceptarse, no obstante, que la acelerada evolución que las sociedades industrializadas han vivido en las últimas décadas ha supuesto un importante cambio en los modos de vida de los individuos. Si bien es cierto que desde los orígenes de la civilización, la evolución ha sido una constante ya que la sociedad está en continuo progreso, en continuo cambio, transformación, lo que caracteriza la situación actual es su mayor celeridad y falta de adaptación. En términos de Kuhn, se trata de períodos revolucionarios donde el progreso cobra un mayor impulso y los ciudadanos se ven forzados a adaptar sus modos de vida a toda prisa durante los períodos interrevolucionarios.

Así, la última revolución es la ocasionada por los avances científicos y tecnológicos que se vienen produciendo desde finales del siglo pasado, principios del presente, y la especial consideración de que una de las caras que este progreso trajo aparejadas es la de la instauración definitiva de la denominada "sociedad del riesgo", con sus directas implicaciones para la seguridad de los ciudadanos.

Es decir, lo que se plantea no es ninguna revolución metodológica o estructural basada en una nueva concepción, sino afirmar que las circunstancias, el paradigma de vida actual, indudablemente han cambiado. Se trata ahora de estudiar cuál debe ser el papel que el derecho penal está llamado a desempeñar la sociedad actual.

\section{CONCLUSIONES}

Desde los orígenes de la disciplina, la relación del derecho penal con las ciencias -puras- ha sido constante y fluida. Con un mayor interés desde el ámbito jurídico hacia las ciencias que viceversa, en el derecho penal se observa un permanente acercamiento, tanto en lo que respecta a su metodología, a los nuevos descubrimientos realizados, como al hecho de convertir la actividad en su propio objeto de regulación.

Así, las sucesivas revoluciones kuhnianas que el derecho penal ha experimentado no son sino el reflejo de las que se produjeron de modo general en la ciencia. Los descubrimientos científicos y la evolución metodológica han marcado el propio discurrir del derecho penal, que ha ido encajando los períodos revolucionarios de progreso científico en la cimentación del conocimiento hasta entonces adquirido.

Esta sucesión de paradigmas llega hasta la actualidad, momento en el que se cuestiona si las propias características de la sociedad actual suponen quiebros en ese paradigma vigente hasta ahora y, de ser así, la necesidad de buscar vías específicas de resolución del conflicto no perdiendo nunca de vista la autonomía del derecho, su propia cientificidad y rigurosidad, y el respeto por los principios limitadores del ius puniendi. 


\section{REFERENCIAS}

Bacigalupo Zapater, E., Delito y punibilidad, Madrid, Civitas, 1983.

Bacigalupo Zapater,E., Manual de Derecho penal.Parte general, Bogotá, Temis, 1996.

Beccaria, C., Tratado de los delitos y de las penas, Granada, Comares, 2008.

Berdugo Gómez de la Torre, I. y Terradillos Basoco, J., "Lección 3. Historia de la Ciencia del Derecho penal", en Demetrio Crespo, E. y Rodríguez Yagüe, C. (coords.), Curso de Derecho penal. Parte general, 3. ${ }^{a}$ ed., Barcelona, Ediciones Experiencia, 2016.

Bettinol, G., El problema penal, Buenos Aires, Hammurabi, 1995.

Bilbeny, N. y Guàrdia, J. (eds.), Humanidades e investigación científica. Una propuesta necesaria, Barcelona, Universidad de Barcelona, 2015.

Calsamiglia, A., Introducción a la ciencia jurídica, 3. a ed., Barcelona, Ariel, 1990.

Carrara, F., Programa del curso de derecho criminal, I, trad. Jiménez de Asúa, L., 2. . ed., Madrid, 1925.

Cerezo Mir, J., "La influencia de Welzel y del finalismo, en general, en la Ciencia del Derecho penal española y en la de los países iberoamericanos", $A D P C P$, t. LXII, I, 2009, pp. 67-92.

Cerezo Mir, J., "La naturaleza de las cosas y su relevancia jurídica", en Problemas fundamentales del Derecho penal, Madrid, Tecnos, 1982.

Cerezo Mir, J., "La polémica en torno al concepto finalista de autor en la ciencia del Derecho penal española", ${ }_{A D P C P}$, tomo XXVIII, 1975, pp. 41-56.

Cuello Contreras, J., El Derecho penal español. Parte general. Nociones introductorias. Teoría del delito, 3. ${ }^{\text {a }}$ ed., Madrid, Dykinson, 2002.

Cuerda Riezu,A.,El legislador y el Derecho penal (una orientación a los orígenes), Madrid, Centro de Estudio Ramón Areces, 1991.

De la Cuesta Aguado, P. M., "La ambigüedad no es programable, racionalización normativa y control interno en inteligencia artificial", Revista de Derecho y proceso penal, n. $^{\circ} 44,2016$. 
Demetrio Crespo, E. (dir.), Neurociencias y Derecho penal: nuevas perspectivas en el ámbito de la culpabilidad y tratamiento jurídico-penal de la peligrosidad, Madrid, Edisofer, 2013.

Echeverría, J. La revolución tecnocientífica, Madrid, FCE, 2003.

Esteve Pardo, J., El desconcierto del Leviatán. Política y derecho ante las incertidumbres de la ciencia, Madrid, Marcial Pons, 2009.

Fasso, G., Storia della filosofía del diritto, III, Bologna, 1970.

Ferrajoli, L., "El Derecho penal mínimo”, en Bustos Ramírez, J. (dir.), Prevención y teoría de la pena, Editorial Jurídica Cono Sur, 1995.

Ferrajoli, L., Derecho y razón. Teoría del garantismo penal, Madrid, Trotta, 1995.

Frommel, M., "Los orígenes ideológicos de la teoría final de la acción de Welzel", ADPCP, tomo XLII, II, 1989.

García-Pablos de Molina, A., Derecho penal. Introducción, Madrid, Universidad Complutense de Madrid, 2000.

Gimbernat Ordeig, E., Concepto y método de la ciencia del Derecho penal, Madrid, Tecnos, 2009.

González, A., "Mecanicismo en el Leviatán de Thomas Hobbes”, en Ho Legon Revista de Filosofía, año 13, n. ${ }^{\circ}$ 13, 2009.

Gracia Martín, L., “La serie ‘infracción-culpabilidad-sanción’ desencadenada por individuos libres como síntesis jurídica indisoluble derivada de la idea y del concepto a priori del derecho", RECPC, 18-18, 2016.

Gracia Martín, L., Fundamentos de dogmática penal. Una introducción a la concepción finalista de la responsabilidad penal, Barcelona, Atelier, 2006.

Hassemer, W., "La ciencia jurídico penal en la República Federal Alemana”, $A D P C P$, tomo XLVI, I, 1993.

Hernández, J. M., El retrato de un dios mortal. Estudio sobre la filosofía política de Thomas Hobbes, Barcelona, Anthropos, 2002.

Herrera Moreno, M., "Nuevo naturalismo punitivo: aspectos de controversia en torno a los discursos penales de base evolucionaria", RECPC, 20-09, 2018. 
Hobbes, T., Leviatán. La materia, forma y poder, de una República Eclesiástica y Civil, Bogotá, Skla, 1982.

Jakobs, G., "Imputación jurídico-penal: desarrollo del sistema a partir de las condiciones de vigencia de la norma", en Jakobs, G. y Struensee, E., Problemas capitales del Derecho penal moderno. Libro homenaje a Hans Welzel, Buenos Aires, Hammurabi, 1998.

Jakobs, G., “¿Qué protege el Derecho penal: bienes jurídicos o la vigencia de la norma?", en Montealegre Lynett, E. (coord.), El funcionalismo en Derecho penal. Libro homenaje al profesor Günther Jakobs, Bogotá, Universidad Externado de Colombia, 2003.

Jakobs, G., Derecho penal. Parte general. Fundamentos y teoría de la imputación, trad. Cuello Contreras, J. y Serrano González de Murillo, J. L., Madrid, Marcial Pons, 1995.

Jiménez de Asúa, L., Principios de Derecho penal. La ley y el delito, 3. a ed., Buenos Aires, Abeledo-Perrot, Editorial Sudamericana, 1997.

Kuhn, T. S., La estructura de las revoluciones científicas, México, FCE, 1975.

Lamo de Espinosa, E. et al., La sociología del conocimiento y de la ciencia, Madrid, Alianza Editorial.

Luzón Peña, D. M., “Alcance y función del Derecho penal”, ADPCP, t. XLII, I, 1989.

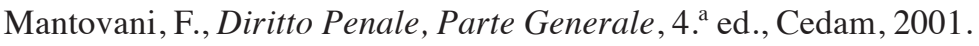

Mir Puig, S., "Posibilidad y límites de una ciencia social del Derecho penal", en Mir Puig, S., Derecho penal y ciencias sociales, Barcelona, Universidad Autónoma de Barcelona, 1982.

Mir Puig, S., Introducción a las bases del Derecho penal. Concepto y método, 2. a ed., Buenos Aires, Euro Editores, Montevideo, B de F, 2003.

Morillas Cueva, L., "Reflexiones sobre el Derecho penal del futuro", RECPC, 04-06, 2002 .

Morillas Cueva, L., Metodología y ciencia penal, Granada, Universidad de Granada, 1990.

Muñoz Conde, F., Introducción al Derecho penal, 2. 'ed., Montevideo, Buenos Aires, B de F, 2001. 
Nuvolone, P., Trent'anni di diritto e procedura penale (Processo e pena nell'opera di Cesare Beccaria), I, Padova, 1969.

Padova Marat, J. P., Plan de legislación criminal, Buenos Aires, Hammurabi, 2000.

Pérez Alonso, E. J., "Las revoluciones científicas del Derecho penal: evolución y estado actual de la dogmática jurídico-penal”, $A D P C P$, tomo L, 1997.

Prittwitz, C., "Sociedad de riesgo y Derecho penal", en Crítica y justificación del Derecho penal en el cambio de siglo, Cuenca, 2003.

Radbruch, G., Introducción a la Filosofía del Derecho, 4. a ed., Madrid, FCE, 1974.

Roxin, C., "El nuevo desarrollo de la dogmática jurídico-penal en Alemania”, en InDret, octubre, 2012.

Roxin, C., Derecho penal. Parte General, tomo I: Fundamentos. La estructura de la Teoría del delito, trad. Luzón Peña, D. M., Díaz y García Conlledo, M., y de Vicente Remesal, J., Madrid, Civitas, 1997.

Roxin, C., Política criminal y sistema del Derecho penal, trad. Muñoz Conde, F., 2. ${ }^{\text {a }}$ ed., Buenos Aires, Hammurabi, 2002.

Ruiz Rodríguez, L. R., “La reforma penal de los delitos contra la salud pública como respuesta a las innovaciones científicas y tecnológicas", RECPC, 18-19, 2016.

Serrano Maíllo, A., Ensayo sobre el Derecho penal como Ciencia. Acerca de su construcción, Madrid, Dykinson, 1999.

Serrano-Piedecasas, J., "El conocimiento científico del Derecho penal", en Arroyo Zapatero, L.A. y Berdugo Gómez de la Torre, J. R. (coords.), Homenaje al Dr. Marino Barbero Santos. In memoriam, vol. I, 2001, pp. 659-698.

Silva Sánchez, J. M., Aproximación al Derecho penal contemporáneo, Barcelona, José M. Bosch, 1992.

Solari Merlo, M. N., “Tecnociencia y Derecho. Análisis de la regulación penal del control de riesgos", Revista de Derecho de la UNED, n. ${ }^{\circ} 23,2018$, pp. 99-141.

Solari Merlo, M. N., “El legislador penal ante la innovación tecnológica. Los daños informáticos en el dilema entre la reflexión filosófica y la práctica jurídico científica", en Moderno discurso penal y nuevas tecnologías memorias [del] III Congreso Internacional de Jóvenes Investigadores en Ciencias Penales, 17, 18 y 19 de junio de 2013, Universidad de Salamanca, España, 2014. 
Sueiro, C. C., Los paradigmas del Derecho penal. Sobre la armonía metodológica del Derecho penal, Buenos Aires, Fabián J. Di Plácido, 2011.

Vázquez Hoys, A. M., Historia del mundo antiguo, vol. I: Próximo Oriente y Egipto, Madrid, Sanz y Torres, 2007.

Von Beling, E., Esquema de Derecho penal. La doctrina del delito-tipo, Buenos Aires, Rodamillans, 2002.

Welzel, H., Introducción a la Filosofía del Derecho: derecho natural y justicia ma-

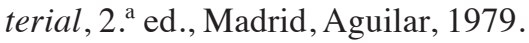

Welzel, H., El nuevo sistema del Derecho penal. Una introducción a la doctrina de la acción finalista, trad. Cerezo Mir, J., Montevideo, Buenos Aires, B de F.

Zaffaroni, E. R., Hacia un realismo jurídico penal marginal, Caracas, Monte Ávila Latinoamericana, 1993.

Zaffaroni, E. R., Tratado de Derecho penal. Parte general, tomo I, Buenos Aires, Ediar, 1998.

Zaffaroni, E. R., Tratado de Derecho penal. Parte general, tomo II, Buenos Aires, Ediar, 1987.

Zaffaroni, E. R., Alagia, A. y Slokar, A., Derecho penal. Parte general, 2. ${ }^{\text {e ed., }}$ Buenos Aires, Ediar, 2002.

Zugaldía Espinar, J. M., Fundamentos de Derecho penal, 3. a ed., Valencia, Tirant lo Blanch, 1993. 